\title{
Analysis of deforestation patterns in the central Menabe, Madagascar, between 1973 and 2010
}

\author{
Dietmar Zinner - Christian Wygoda - Leon Razafimanantsoa • \\ Rodin Rasoloarison - Herizo T. Andrianandrasana • \\ Jörg U. Ganzhorn • Frank Torkler
}

Received: 17 September 2012/Accepted: 3 May 2013/Published online: 24 May 2013

(c) The Author(s) 2013. This article is published with open access at Springerlink.com

\begin{abstract}
The central Menabe region still holds the largest remnant of dry forest in western Madagascar. These forests are home to high floral and faunal diversity including a number of local and regional endemics. The forests of the central Menabe have been classified as conservation hotspots. However, pressure on these forests is strong and deforestation continues on a large scale. To quantify recent forest loss, we used a series of satellite images (1973-2010) for estimating annual deforestation rates. The overall rate was $0.67 \%$, but it accelerated during certain periods to over $1.5 \%$ with a maximum of $2.55 \%$ per year between 2008 and 2010. Not all areas within the forest block of the central Menabe are affected similarly. Areas surrounding existing clearings show the highest losses of largely undisturbed forest. If deforestation continues at the same rate as during the last years, $50 \%$ of the 1973 forest cover will be gone within the next 11-37 years.
\end{abstract}

\section{Zinner $(\bowtie)$}

Cognitive Ethology Laboratory, Deutsches Primatenzentrum, Göttingen, Germany

e-mail: dzinner@gwdg.de

\section{Wygoda - F. Torkler}

Landscape Management and Nature Conservation, Hochschule für nachhaltige Entwicklung Eberswalde (FH),

Eberswalde, Germany

\section{Razafimanantsoa $\cdot$ R. Rasoloarison}

Behavioral Ecology and Sociobiology Unit, Deutsches

Primatenzentrum, Göttingen, Germany

H. T. Andrianandrasana

Durrell Wildlife Conservation Trust, Antananarivo, Madagascar

J. U. Ganzhorn

Biozentrum Grindel, Zoologisches Institut,

Universität Hamburg, Hamburg, Germany
Keywords Madagascar - Deforestation - Dry forest . Satellite image time series · Remote sensing - Political crisis

\section{Introduction}

Madagascar, the world's fourth largest island of approximately $587,000 \mathrm{~km}^{2}$, is located off the south-eastern coast of Africa. It is regarded as one of the major biodiversity hotspots (Myers et al. 2000), because it harbours exceptional biota with high overall diversity and levels of endemism (Goodman and Benstead 2005). At the same time, its plant and animal species are among the most endangered (Mittermeier et al. 2004; IUCN 2011). As in other parts of the tropics, habitat loss and fragmentation are among the most pervasive causes of biodiversity loss (Laurance et al. 2000; Geist and Lambin 2002; Fahrig 2003; Gardner et al. 2010; Irwin et al. 2010). The vast majority of the terrestrial biota is forest dependent, but deforestation has reached alarming proportions. Although historical estimates of national forest cover of Madagascar are difficult and somehow controversial (e.g. Dufils 2003), the tendency of forest loss is obvious. Dufils (2003) reported deforestation rates for evergreen forest formations of 102,000 ha per year in the period from 1950 to 1999 . These estimates are similar to those of Green and Sussman (1990) for the eastern rain forests which had lost $50 \%$ between 1950 and 1985 with a rate of 111,000 ha per year.

Monitoring and analysing deforestation in Madagascar was focussed on the eastern humid forests (Green and Sussman 1990; Nelson and Horning 1993; Dufils 2003; Bollen and Donati 2006; Vågen 2006). However, deforestation rates in the western dry deciduous forests with their comparable levels of endemism and biodiversity were 
similarly high or even higher (Smith 1997; Whitmore 2000; Harper et al. 2007; Scales 2011). It was estimated that over $97 \%$ of Madagascar's dry deciduous forests had already disappeared by the year 2000 (WWF 2001) and with them unique aspects of Malagasy biodiversity (Whitmore and Sayer 1992; Ganzhorn et al. 2001; Allnutt et al. 2008). This matches the situation of most tropical dry forests that have been neglected due to an emphasis on humid tropical forests (Janzen 1988; Lerdau et al. 1991; Bellefontaine et al. 1997).

Causes for forest removal in Madagascar vary regionally (Gorenflo et al. 2011). However, the main direct cause of forest loss in western Madagascar is deforestation through intentional burning to clear land for agriculture, locally known as hatsake, either for subsistence or for the market production (Scales 2011, 2012). With an expanding rural population and increasing degradation of existing arable lands, the pressure on the remaining forest is extremely high. Selective logging poses additional threats to forest habitats (Whitehurst et al. 2009).

A priority-setting workshop concerning Madagascar in 1995 identified several sites of the dry deciduous forest ecosystem in need of immediate biodiversity protection, among them were the southern and the central Menabe regions (Ganzhorn et al. 1997; Hannah et al. 1998). In 1997, a large contiguous block of the dry forest in the southern Menabe became legally protected as the KirindyMitea National Park, one of the first national parks in the western forest zone (Décret no 97-1453, 18 December 1997 by the Ministère de l'Environnement, des Eaux et Forêts). The central Menabe region includes the area between the Morondava River in the south and the Tsiribihina River in the north. The northern part of the region, between Tomitsy and Tsiribihina rivers, still contains one of the largest tracts of dry deciduous forests left in Madagascar, the Kirindy-Ambadira Forest Complex (KAFC). Prior to the establishment of Kirindy-Mitea National Park, the only protected area within the region was the Special Reserve Andranomena (approx. 7,000 ha), which is located south of the KAFC and south of the Tomitsy River. However, it has already lost most of the local endemics because of forest degradation (Smith et al. 1997; Ganzhorn and Schmid 1998; Tidd et al. 2001).

The central Menabe has experienced a long history of forest conversion into agriculture, both for plantations and subsistence (Scales 2011), and further conversion of the remaining forests in the central Menabe poses serious threats to the survival of several endemic vertebrates. The global distribution of four vertebrate species is restricted to the forested areas between the Morondava and Tsiribihina rivers, with the last remaining population of the giant jumping rat (Hypogeomys antimena), the largest living endemic rodent of Madagascar (Sommer et al. 2002; Young et al.
2008); the only population of Madame Berthe's mouse lemur (Microcebus berthae), the smallest primate of the world (Rasoloarison et al. 2000; Yoder et al. 2000); the flattailed tortoise (Pyxis planicauda; Tidd et al. 2001); and a frog (Aglyptodactylus laticeps; Glaw et al. 1998; Glos et al. 2008). Sixteen other vertebrate species with extremely restricted ranges are found in the KAFC including the striped mongoose (Mungotictis decemlineata; Razafimanantsoa 2003) and the white-breasted mesite (Mesitornis variegata; Durbin et al. 2005; reviewed by Goodman and Raselimanana 2008). Tree species diversity is notably high with more than 200 species (Abraham et al. 1996; Rakotonirina 1996). Current pressures in the region stem primarily from an expanding human population which uses slash-and-burn agriculture (for subsistence and cash crop), legal and illegal selective logging and animal trapping for subsistence. There have been only five legal timber harvesters in the region, four of which held harvesting lots defined by the service of Environment and Forests in the Central Menabe region; all other activity was considered illegal. For instance, during the monitoring of the northeastern corner of the Kirindy Forest in 2002, the Waters and Forests service seized $400 \mathrm{logs}$ and destroyed 40 lemur traps. In order to insure the survival of the endemic species and to protect their habitat, an initiative was launched to improve the legal protection of the KAFC and to create a protected area, called 'Aire Protégée Menabe Antimena' (Ministère de l'Environnement, des Eaux et Forêts 2006).

To further support the process towards creating a permanent protected area in the central Menabe and to identify deforestation hotspots within the region, we performed a temporal and spatial analysis of forest loss in KAFC for the last 37 years (1973-2010) with special interest in the deforestation rates during years of civil unrest, such as during the transition between the presidents Rasiraka and Ravalomanana from 2001/2002 and after Madagascar's unconstitutional change in government in 2009 .

\section{Study area}

The study area is located in the dry deciduous forest of coastal western Madagascar between the Tomitsy $\left(44^{\circ} 35^{\prime} \mathrm{E}, 20^{\circ} 08^{\prime} \mathrm{S}\right)$ and the Tsiribihina rivers $\left(44^{\circ} 37^{\prime} \mathrm{E}\right.$, $19^{\circ} 44^{\prime} \mathrm{S}$ ) (Fig. 1). The Kirindy Forest constitutes the southern part and the Ambadira Forest the northern part of the KAFC. In the west, the KAFC adjoins the coastal dunes and marshes, and in the east, the forest borders savannah grassland. The climate is characterized by pronounced seasonality with little or no rain from April to November, followed by a rainy season from December to March (Ganzhorn 1995a; Sorg and Rohner 1996). The mean annual precipitation between 1906 and 1993 was 767 mm/year 
Fig. 1 Map of Madagascar showing the geographical position of the study area and the Kirindy-Ambadira Forest Complex (KAFC) in the central Menabe between Tomitsy and Tsiribihina rivers.

$\mathrm{CNFEREF}=$ forest concession Formation, d'Etudes et de Recherche en Environnement et Foresterie and the Kirindy Forest research station of the German Primate Center. Dark grey areas along the Tsiribihina River indicate lakes and marshes of the Centre National de

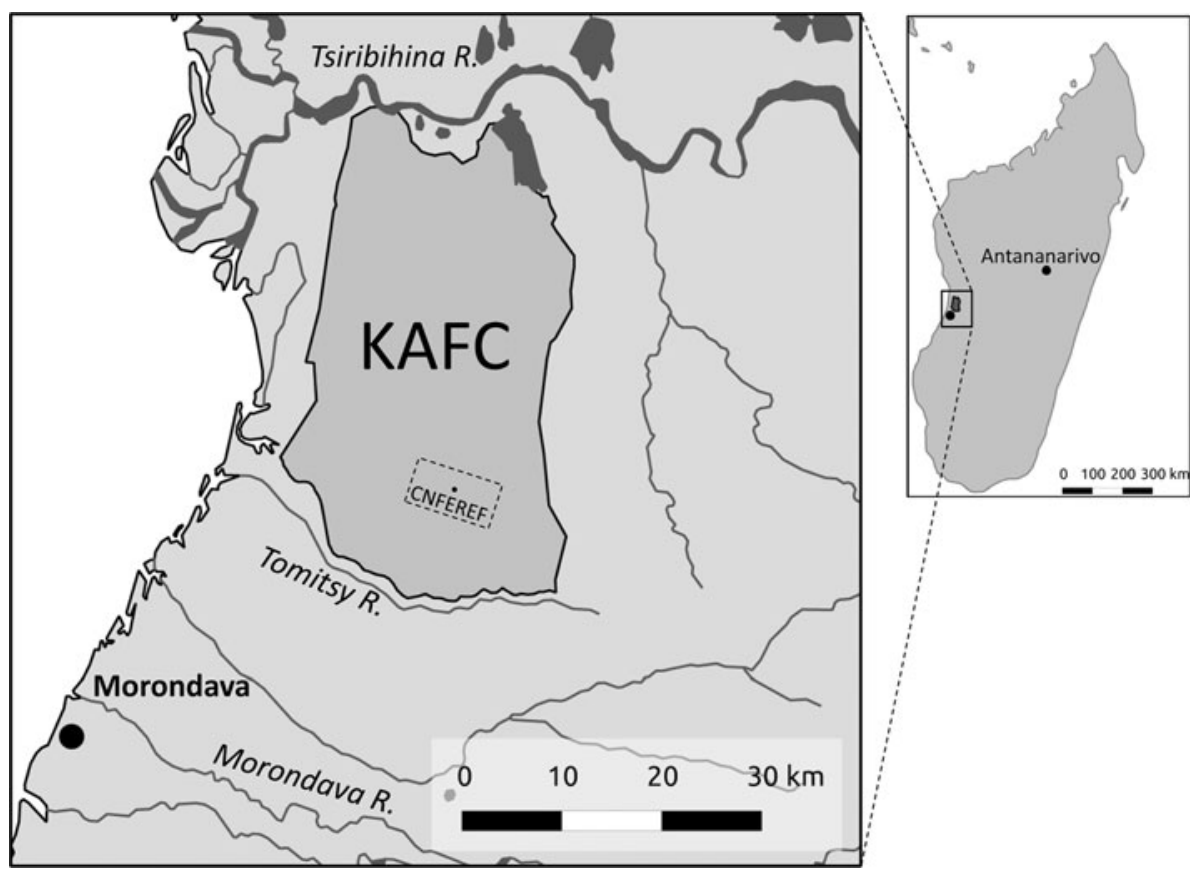

(Sorg and Rohner 1996) with a tendency of increased variation over time (Ganzhorn 1995b). Mean annual rainfall from 2000 to 2009 (including 3 cyclone years) at the research station of the German Primate Center in the Kirindy Forest was $945 \mathrm{~mm}$, also with increased variation over time (Kappeler and Dammhahn unpublished data).

Forest structure and phenology are not well studied in most parts of the KAFC, with the exception of the concession of the Centre de Formation Professionnelle Forestière, CFPF (now Centre National de Formation, d'Etudes et de Recherche en Environnement et Foresterie, CNFEREF), in the Kirindy Forest (Fig. 1). Ganzhorn and Sorg (1996) provide a detailed description of the site characteristics. Forest was described as a dense formation with a closed canopy at least during the rainy season when there is leaf cover and trees rarely exceed $20 \mathrm{~m}$ in height. Further information about forest structure and phenology for the CNFEREF concession can be found in Rakotonirina (1996) and Sorg and Rohner (1996). The KAFC is traversed by the Route Nationale 8 in north-south and in east-west directions by several straight $3-4-\mathrm{m}$-wide tracks cut through the forest in the 1970s and 1980s for oil exploration.

\section{Methods}

\section{Forest classification}

The forest in our study area would be classified 'Western dry forest', and it shows a number of traits that are characteristic for seasonally dry deciduous forests (Du Puy and Moat 1996; Moat and Smith 2007): most trees of the canopy layer are deciduous; a herbaceous layer is absent (except along dirt roads where grasses spread); flowering often precedes the first flush of leaves; and trees show several adaptations to cope with prolonged water stress (Sorg et al. 2003). For our classification, we followed Rakotonirina's (1996) description of forest structure in the study area and defined forest as stands of trees with dbh $>10 \mathrm{~cm}$, a height of $>12 \mathrm{~m}$ and at least $75 \%$ closed canopy during the rainy season (excluding secondary regrowth, see below).

We established 121 ground control points between 2001 and 2010. Control points were either visited on the ground or, in more remote areas, were evaluated when one of the authors (HA) carried out an aerial survey in 2005. In an area with at least a $50 \mathrm{~m}$ radius around each point, we assessed whether the vegetation corresponded to our forest definition. In zones with cleared forest, if not used for agricultural purposes, the vegetation consists of secondary formations, shrub and savannah grassland.

Satellite data and analysis

Remote sensing has been successfully applied in deforestation monitoring in many studies in the tropics including Madagascar (e.g. Nelson and Horning 1993; Viña et al. 2004; Vågen 2006; Duveiller et al. 2008; Hansen et al. 2008). With the opening of the Landsat 7 archive by the US Geological Service (USGS) in January 2009, a wide array of satellite scenes became available. To cover our complete study period of more than 35 years, we had to use data from a variety of sensor systems, because no single system was in operation long enough. Thus, four Landsat 7 scenes, 


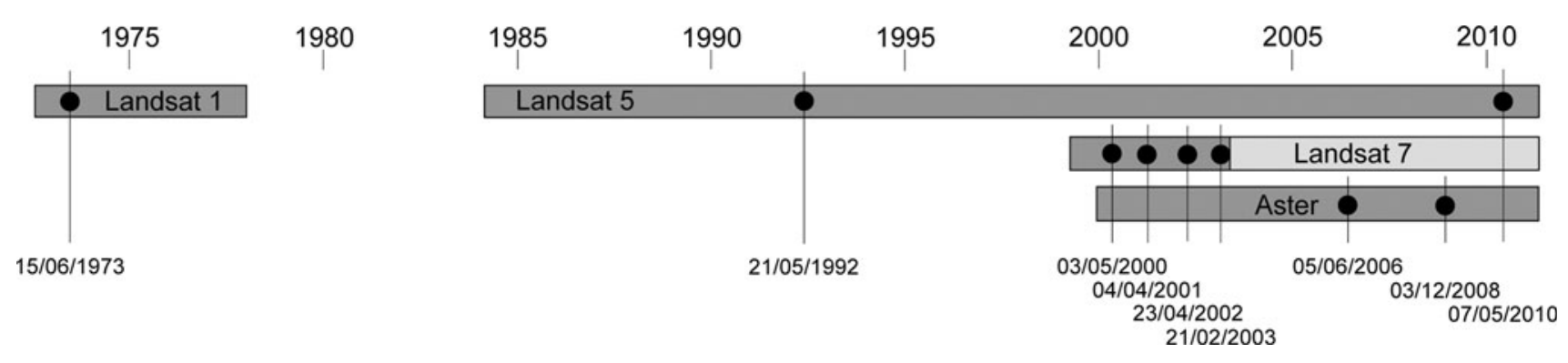

Fig. 2 Earth observation satellites and satellite scene dates used

together with one Landsat 1, two Landsat 5 and two ASTER scenes were the base for the establishment of the deforestation time series. Figure 2 shows scene dates used for this analysis. All scenes have been resampled to the extent and spatial resolution (pixel size $30 \mathrm{~m} \times 30 \mathrm{~m}$ ) of the 1992 Landsat scene.

We aimed to select satellite scenes which were maximally cloud free and which did not represent data from the rainy season. Most of our selected scenes were sampled in May or June when the agricultural areas were already harvested and in comparison with forest almost vegetation free. Forests and harvested agricultural areas showed a significant difference in near infrared reflection and could therefore be distinguished clearly.

Each Landsat scene was processed with an unsupervised classifier yielding a 25-class partition for each scene. These classes were combined with the derived Normalized Difference Vegetation Index to determine the mean NDVI value for each class (Ingram and Dawson 2005). In the used scenes, forests yield the highest NDVI values, and almost vegetation-free agricultural areas produced only low NDVI values. A threshold value was established for each scene independently by visually comparing the resulting forest/non-forest map with the input satellite scene texture of known forested and non-forested areas (based on several years of field experience of several of the authors in the region). The yielded threshold values range from 0.2 to 0.4 .

Both ASTER scenes show areas of both good and bad plant conditions indicated by corresponding NDVI values: Smaller areas mainly in the north-east show high NDVI values, most likely caused by local precipitations at the onset of the rain season in November 2008 (acquisition date 03 December 2008), the rest show overall low values due to long dryness. Therefore, each scene was divided into smaller portions-the assessment areas described in Table 2 and shown on the result map (Fig. 5). These areas were assessed using the classifying/NDVI threshold approach described above. All used satellite scenes were cloud free with the exception of the 2001 scene, where $1.5 \%$ of the area of interest was covered. Since opaque clouds were only recorded above areas clearly classified as forest in the subsequent scene, we inferred forest presence also for the 2001 scene.

Finally, each forest/non-forest map was smoothed using a $3 \times 3$ mode filter in order to reduce noise of saltand-pepper effects resulting from pixel-based NDVI classification. These maps were aggregated into a single deforestation time series. Secondary regrowth is ignored: pixels which were categorized as non-forest in one time step, but were classified as (re)forested in one of the subsequent time steps still were assigned as non-forest. This accounts for the lower ecological value of second-growth forests (lower floral and faunal diversity), since the species composition of plant and animal communities often differs between secondary and old-growth forests (Chazdon 2003; Dunn 2004; Lugo and Helmer 2004; Gardner et al. 2007). The ecological value of secondary forest in the central Menabe has not been studied in detail (Sorg 2006), but by comparing largely undisturbed and secondary forests in the region, it became obvious that lemur diversity and population sizes are lower in secondary forests and endemic species, such as Madame Berthe's mouse lemur or the giant jumping rat depend on dense old-growth dry forest and are not found in secondary regrowth (Smith 1997; Smith et al. 1997; Ganzhorn et al. 1999; Sommer et al. 2002; Dammhahn and Kappeler 2008).

\section{Temporal structuring}

We divided the total monitoring interval of 37 years (1973-2010) into eight periods using the acquisition dates of the nine satellite images as separators. Since the eight periods are not of equal lengths (Table 1), we normalized forest loss by using deforestation per year: forest loss within period (ha)/length of period (d) $* 365$.

\section{Spatial structuring}

We assumed that not all regions within the study area were similarly impacted by deforestation. Forest areas adjacent to villages and around already existing clearings probably experience higher deforestation rates than others (Mertens and Lambin 1997; Etter et al. 2006; Mon et al. 2012). 
Table 1 Dates and duration (days) of study periods

\begin{tabular}{llr}
\hline Start & End & Duration \\
\hline 15 Jun 1973 & 20 May 1992 & 6,915 \\
21 May 1992 & 02 May 2000 & 2,904 \\
03 May 2000 & 03 Apr 2001 & 336 \\
04 Apr 2001 & 22 Apr 2002 & 384 \\
23 Apr 2002 & 20 Feb 2003 & 304 \\
21 Feb 2003 & 04 Jun 2006 \\
05 Jun 2006 & 02 Dec 2008 & 1,200 \\
03 Dec 2008 & 06 May 2010 & 912 \\
15 Jun 1973 & 06 May 2010 & 541 \\
\hline
\end{tabular}

Table 2 List of assessment areas, area size and whether the areas contained at least one settlement

\begin{tabular}{lcrl}
\hline Name & Id code & Size (ha) & Settlement \\
\hline Tsimafana & 1 & 7,112 & Yes \\
Tsianaloka & 2 & 3,269 & Yes \\
Ambadira & 3 & 15,025 & No \\
Salapeno & 4 & 3,425 & No \\
Lambokely & 5 & 2,328 & Yes \\
Masiposa & 6 & 6,446 & No \\
Forêt d'Ankirisa & 7 & 4,627 & No \\
Beroboka North & 8 & 8,798 & Yes \\
Corridor North & 9 & 5,686 & Yes \\
Beroboka South & 10 & 6,245 & Yes \\
Corridor South & 11 & 11,490 & Yes \\
Kirindy Village & 12 & 4,942 & Yes \\
CNFEREF & 13 & 18,037 & No \\
Marofandilia North & 14 & 1,556 & Yes \\
Marofandilia East & 15 & 5,378 & Yes \\
Total area & & 104,364 & \\
\hline
\end{tabular}

Therefore, we partitioned the study area into 15 arbitrary geographical assessment areas for the statistical analysis. Each area was named after a village, the concession holder (e.g. CNFEREF) or the name was taken from topographical maps (1:100.000, FTM, Institut National de Géodésie et de Cartographie 1956, reprint 1980) (Table 2).

\section{Results}

Our forest/non-forest classification in the final map was verified at 121 ground control points. All 78 forest control points $(100 \%)$ and $88.4 \%$ of the 43 non-forest points were classified correctly (total classification user accuracy $95.9 \%$ ), that is, we tended to classify more deforested areas as forest than vice versa. By sometimes wrongly

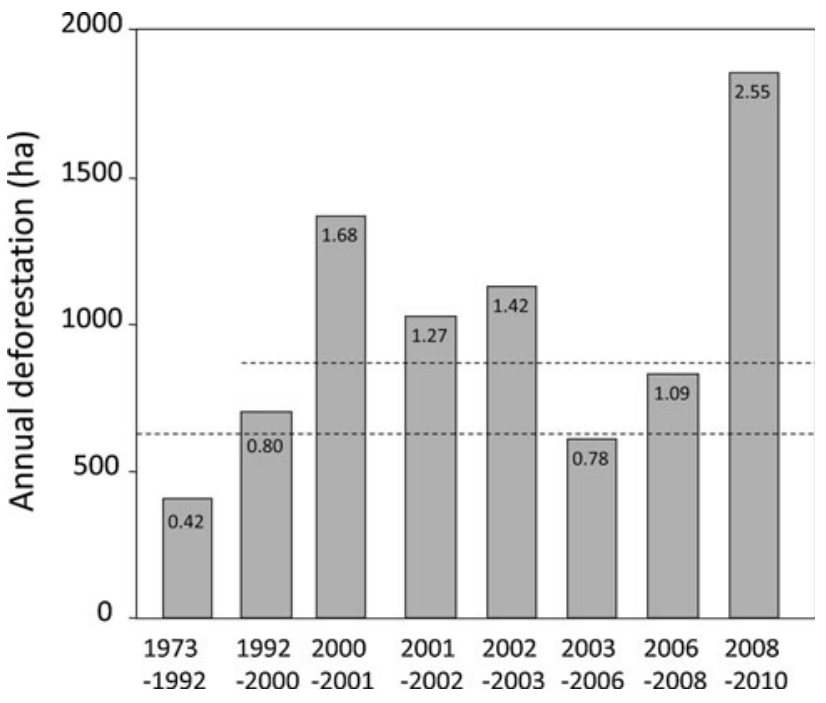

Fig. 3 Absolute annual deforestation rates (ha) within KAFC. Lower dashed line: annual deforestation rate over the complete period of 37 years $\left(1973-2010 ; 631.6\right.$ ha a $^{-1}$ or $0.67 \% \mathrm{a}^{-1}$ of the 1973 forest cover); upper dashed line: annual deforestation rate over the period of the last 18 years $\left(1992-2010 ; 872.7 \mathrm{ha} \mathrm{a}^{-1}\right.$ or $1.0 \% \mathrm{a}^{-1}$ of the 1992 forest cover). Numbers in columns refer to relative annual deforestation rates (\%) within each period

classifying forest-free areas as forest, we underestimated the true proportion of deforestation making our classification a conservative and robust approach. The proportion of deforestation tends to be even higher than our estimate.

In 1973, the remaining forest cover of the KAFC was approximately 94,743 ha. Within the subsequent 37 years, the forest cover was reduced by 23,353 ha $(24.6 \%)$ to only 71,390 ha which means an average annual deforestation rate of 631.6 ha or $0.67 \%$ based on the 1973 forest cover. When taking into account only the period from 1992 to 2010, the annual rate was 872.7 ha or $1.00 \%$ of the 1992 forest cover. Annual deforestation rates were relatively low between 1973 and $1992(0.42 \%)$ but exceeded $1.3 \%$ between 2000 and 2003 (Fig. 3). The rate subsequently dropped to less than $0.8 \%$ in the period between 2003 and 2006. Recently, deforestation increased again above $1 \%$ in the period from 2006 to 2008 and up to $2.55 \%$ between 2008 and 2010.

Not all areas within the KAFC have been equally affected by forest loss. Deforestation rates were highest around certain settlements, namely Lambokely, Kirindy Village, Beroboka North and South and Marofandilia (Figs. 4, 5).

The most dramatic forest loss was detected in the period from 2008 to 2010 as extensions of already existing agricultural clearings such as Lambokely, Beroboka North and South and along the northern limit of the KAFC at Tsimafana and Tsianaloka (Figs. 4, 5). 
Fig. 4 Relative annual forest loss (\%) of 15 areas within the KAFC in 8 study periods. Size of circles depict magnitudes of deforestation rates (larger circles correspond to higher deforestation rates). For higher rates exact figures are included

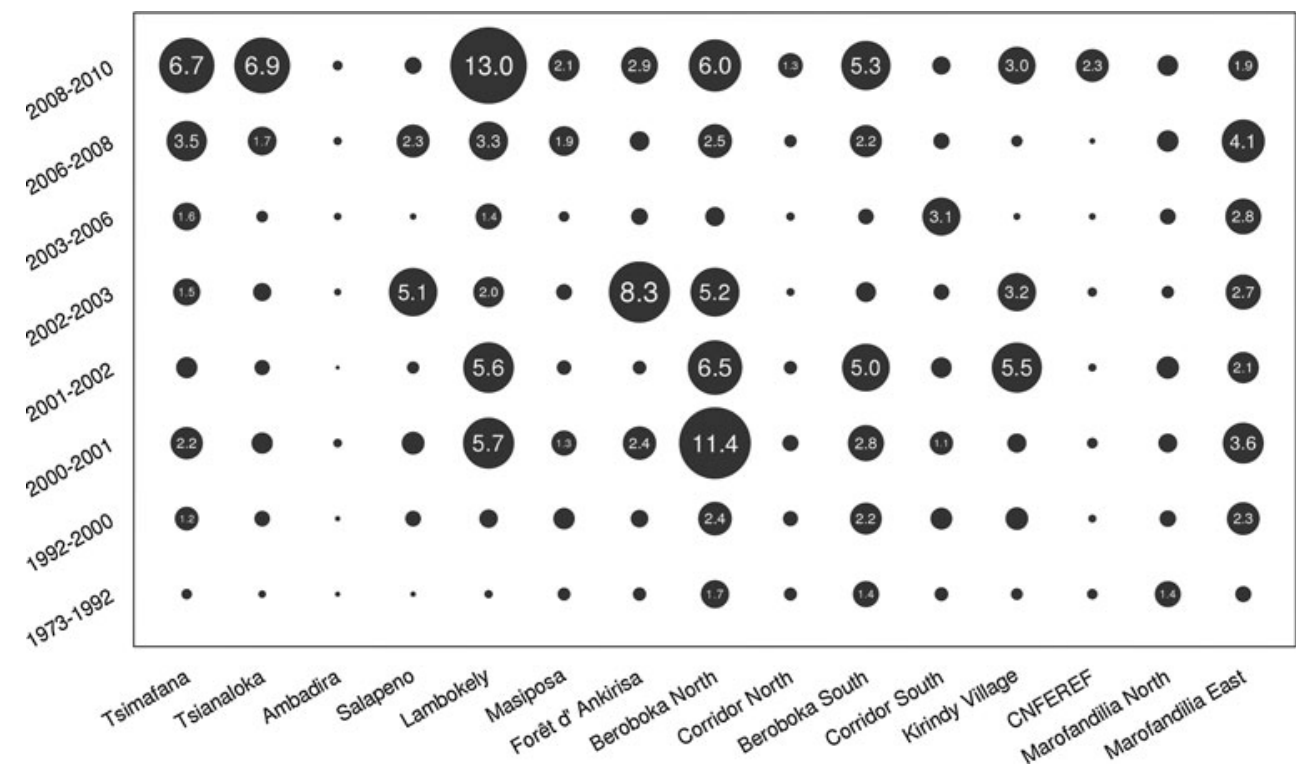

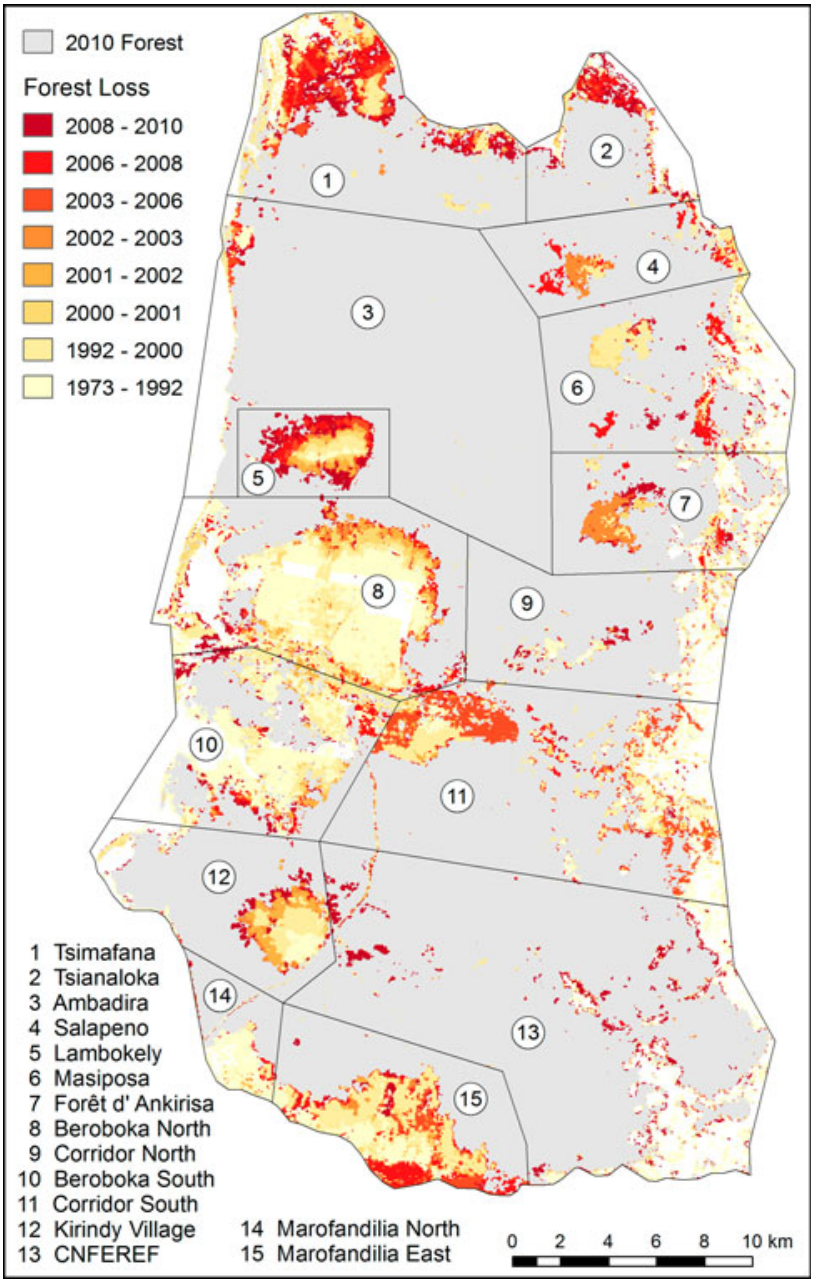

Fig. 5 Map of forest loss in the KAFC 1973-2010. Grey colour indicates remaining forest cover in 2010. Study area partition is overlaid
Table 3 Comparison of forest loss calculated by the present study (\% per year) with data from Tidd et al. (2001) and Scales (2011)

\begin{tabular}{lll}
\hline Period & Forest loss $\mathrm{a}^{-1} \%$ & Study \\
\hline $1963-1984$ & 0.40 & Tidd et al. \\
$1984-1993$ & 1.10 & Tidd et al. \\
$1973-1992$ & 0.4 & Scales \\
$1992-1999$ & 0.4 & Scales \\
$1999-2005$ & 1.0 & Scales \\
$1973-1992$ & 0.42 & This study \\
$1992-2000$ & 0.80 & This study \\
$2000-2010$ & 1.24 & This study \\
\hline
\end{tabular}

\section{Discussion}

The time series analysis of satellite images suggests rapid deforestation in the central Menabe. Our estimates of deforestation rates match those of Tidd et al. (2001) for the region between the Tomitsy River and the Tsiribihina River and those of Scales (2011). Although their study periods are not directly comparable to ours and their forest definition seems to be broader than the one we applied, the magnitude of annual deforestation rates corresponds to our results (Table 3), with a general acceleration over the years despite the fact that forest clearance for agriculture has been illegal since 1987 (Décret no 87-143, 20 April 1987 by the Ministère de l'Environnement, des Eaux et Forêts).

Deforestation of the area was already documented by Smith (1997) and Smith et al. (1997). Deforestation in Menabe is regarded as an almost irreversible process, because these forests have poor regenerative power due to the scarcity or lack of secondary colonizing species and 
disturbed areas are rapidly invaded by alien plant species (Genini 1996; Lowry II 1997). Also, secondary regrowths are unsuitable habitats for the endemic forest species (e.g. Madame Berthe's mouse lemur, giant jumping rat; Sommer et al. 2002; Dammhahn and Kappeler 2008). Thus, the value of such secondary habitats for preserving the forest endemics is highly questionable.

Reasons for deforestation are manifold as in other parts of Madagascar (Brooks et al. 2009; Gorenflo et al. 2011). In the case of central Menabe, forest clearance for agriculture is the most important proximate factor (Smith 1997; Smith et al. 1997). This is particularly obvious in the vicinity of already existing slash-and-burn areas such as the hatsake of Lambokely, Kirindy Village, Beroboka North and South and Marofandilia. However, as Scales $(2011,2012)$ pointed out, different social, political and economic factors drive deforestation in the central Menabe as in other parts of southwestern Madagascar (Casse et al. 2004). For instance, in Tsimafana (zone 1), forest is converted in large quantities into maize fields for market production or in the north-eastern areas of Menabe (zones 4 Salapeno, 6 Masiposa and 7 Ankirisa), the extension of cattle pasture seems to be the main cause for habitat clearing, as local people are predominantly cattle breeders and only marginally practise farming. These areas are of particular interest because deforestation has taken place here within the last years without being noticed by the local authorities. Large concessions and plantations (e.g. the sisal plantation around Beroboka) with subsequent immigration of non-autochthonous people as workers into the area had an over-proportional impact on deforestation and the demography of the region (Scales 2011).

The extension of already existing clearings not only reduces forest cover but can result also in forest fragmentation. The danger of fragmentation becomes particularly obvious in the Corridor South area (area partition 11) where further forest loss will immediately lead to the separation of the southern Kirindy and the northern Ambadira forests. The cleared areas would constitute a dispersal barrier for forest-dependent species, resulting in a cut-off of gene flow between the Kirindy and Ambadira parts of the KAFC. There is already evidence for a cut-off. A rapid lemur survey in 2007 (Kappeler et al. unpublished data) revealed that the corridor is only functional for Microcebus murinus and to a lesser degree for Mirza coquereli and Phaner furcifer.

In addition to the results of the deforestation identified by satellite images, selective logging is another factor that has a negative impact on the Menabe forests. In contrast to slashand-burn, which is obvious in the satellite data, selective logging also degrades the forest, but is difficult to measure with satellite images. Reliable data on logging are not available.

It might be that deforestation in KAFC was accelerated by an additional factor. It is noticeable that deforestation activities in the central Menabe have been extremely high during times when central governmental control was low, a temporal coincidence also reported by Vågen (2006) for deforestation in parts of the eastern highlands of Madagascar. In the short period between 2000 and 2003, when a political conflict almost turned into a civil war, deforestation increased from less than 500 ha per year $(0.5 \%)$ in the period from 1973 to 2000 to more than 1,100 ha $(1.4 \%)$ in the following three years. In the post-crisis period from 2003 to 2008, intensive conservation activities were launched in the central Menabe with a series of talks with local authorities and villagers, confiscation of illegally logged wood, surveys and monitoring activities. During this period, the deforestation rate dropped to 706 ha per year (0.9\%). In 2009 and 2010, with a new political crisis associated with considerable civil unrest and reduced governmental control, the deforestation rate in the central Menabe increased to a new record high of more than 1,890 ha per year $(2.55 \%)$. Although we cannot provide any statistical evidence for a relationship between political instability with low legal enforcement and the increase in conversion of forest into agriculture, the temporal coincidences are notable. An elevated deforestation rate during times of political instability, in particular on the subsistence level, seems to be a widespread phenomenon (Deacon 1994; Didia 1997; Vågen 2006; Randriamalala and Liu 2010; Freudenberger 2010; Innes 2010; World Bank 2010).

In the interest of conservation of natural resources and biodiversity in the Central Menabe region, all relevant stakeholders such as the Fanamby NGO, Durrell Wildlife Conservation Trust, Madagascar National Parks, CNFEREF, WWF, OPCI (l'Organisation Publique de Coopération Intercommunale) and government offices have united to form the 'Platform for Conservation of Biodiversity and Development in Central Menabe'. The 'platform' agreed that the weak or even non-existing law enforcement is one of the key issues in relation to deforestation in Menabe. The regional direction of environment and forests (DREF) has recently set up the service of investigation and control (SRIC) which manages infractions and law. The main concern of this service is to investigate and follow-up threats and pressures in the forest. However, apparently the service is lacking funds and personnel to implement field visits and control or to work closely with local communities to assist through participatory ecological monitoring. One option to reduce deforestation in Menabe would be technical and financial support of the SRIC.

\section{Future perspectives}

Assuming that deforestation will continue at the same amount $\left(631.2 \mathrm{ha} \mathrm{a}^{-1}\right)$ as over the whole study period from 


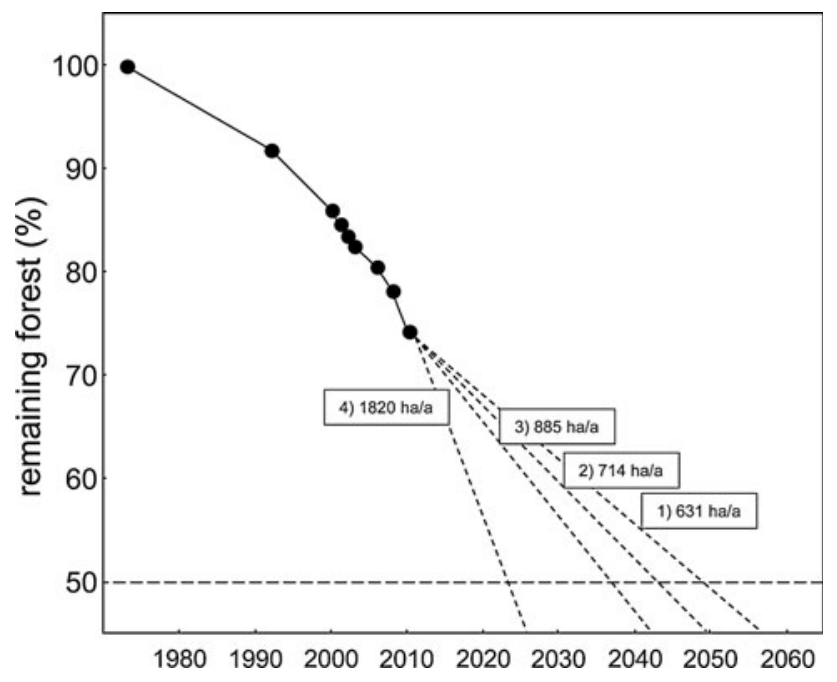

Fig. 6 Reduction in forest cover in the KAFC and projected change under four deforestation scenarios: an annual deforestation (1) similar to the overall annual amount in the period from 1973 to 2010 ; (2) similar to the annual amount in the period from 1992 to 2010; (3) similar to the annual amount within the last 10 years; and (4) similar to the annual amount in the period from 2008 to 2010 . Forest cover in 1973 was set at $100 \%$

1973 to 2010, the KAFC will have lost $50 \%$ of the 1973 forest cover by 2049 (Fig. 6). In case of deforestation continues with an average rate similar to that over the period from 1992 to $2010\left(713.9 \mathrm{ha}^{-1}\right)$, the forest cover will be reduced to only $50 \%$ by 2043 . With an annual deforestation of $885.2 \mathrm{ha} \mathrm{a}^{-1}$ similar to the rate within the last 10 years, $50 \%$ of the 1973 forest cover will be gone by 2037. However, if deforestation continues with an average annual deforestation as between 2008 and 2010 $\left(1,820.4 \mathrm{ha} \mathrm{a}^{-1}\right)$, but with no further acceleration, the forest cover will be reduced to $50 \%$ by 2023. Such an annual deforestation will lead to a complete loss of forest by 2,049 and with it most, if not all, endemic species. These projections show alarming trends and are cause for serious concern and should lead to an acceleration of conservation activities.

Acknowledgments We would like to thank the Global Conservation Program (GCP) of Conservation International for financial support, the Aviation sans Frontière Belge for their help with the aerial surveys, the local forest committees, Anselme Toto Volahy and Francisco Rakotombololona for their assistance during the ground truthing process. We thank the Direction Régionale de l'Environnement et des Forêts de Menabe and the Madagascar National Parks for their cooperation. Thanks to Tanja Haus, Gisela Fickenscher, Melanie Dammhahn and Moritz Rahlfs for their comments on an earlier version of the paper.

Open Access This article is distributed under the terms of the Creative Commons Attribution License which permits any use, distribution, and reproduction in any medium, provided the original author(s) and the source are credited.

\section{References}

Abraham JP, Rakotonirina B, Randrianasolo M, Ganzhorn JU, Jeannoda V, Leigh EG (1996) Tree diversity on small plots in Madagascar: a preliminary review. Rev Ecol (Terre Vie) 51:93-116

Allnutt TF, Ferrier S, Manion G, Powell GVN, Ricketts TH, Fisher BL, Harper GJ, Irwin ME, Kremen C, Labat JN, Lees DC, Pearce TA, Rakotondrainibe F (2008) A method for quantifying biodiversity loss and its application to a 50-year record of deforestation across Madagascar. Conserv Lett 1:173-181. doi: 10.1111/j.1755-263X.2008.00027.x

Bellefontaine R, Gaston A, Petrucci Y (1997) Aménagement des forêts naturelles des zones tropicales sèches. Cahier Conservation FAO 32. FAO, Rome

Bollen A, Donati G (2006) Conservation status of the littoral forest of south-eastern Madagascar: a review. Oryx 40:57-66. doi: $10.1017 / \mathrm{S} 0030605306000111$

Brooks CP, Holmes C, Kramer K, Barnett B, Keitt TH (2009) The role of demography and markets in determining deforestation rates near Ranomafana National Park, Madagascar. PLoS ONE 4:e5783. doi:10.1371\%2Fjournal.pone.0005783

Casse T, Milhøj A, Ranaivoson S, Randriamanarivo J (2004) Causes of deforestation in southwestern Madagascar: what do we know? Forest Pol Econ 6:33-48. doi:10.1016/S1389-9341(02)00084-9

Chazdon RL (2003) Tropical forest recovery: legacies of human impact and natural disturbances. Perspect Plant Ecol Evol Systemat 6:51-71. doi:10.1078/1433-8319-00042

Dammhahn M, Kappeler PM (2008) Small-scale coexistence of two mouse lemur species (Microcebus berthae and M. murinus) within a homogeneous competitive environment. Oecologia 157:473-483. doi:10.1007/s00442-008-1079-x

Deacon RT (1994) Deforestation and the rule of law in a cross-section of countries. Land Econ 70:414-430

Didia DO (1997) Democracy, political instability and tropical deforestation. Global Environ Change 7:63-76. doi:10.1016/ S0959-3780(96)00024-6

Du Puy D, Moat J (1996) A refined classification of the primary vegetation of Madagascar based on the underlying geology: using GIS to map its distribution and to assess its conservation status. In: Lourenço WR (ed) Proceedings of the International Symposium on the 'Biogeography de Madagascar', Paris, September 1995. Editions de l'ORSTOM, Paris, pp 205-218

Dufils J (2003) Remaining forest cover. In: Goodman SM, Benstead JP (eds) The natural history of Madagascar. The University of Chicago Press, Chicago, pp 88-96

Dunn RR (2004) Recovery of faunal communities during tropical forest regeneration. Conservat Biol 18:302-309. doi:10.1111/j. 1523-1739.2004.00151.x

Durbin J, Ratsimbazafy J, Volahy A, Kappeler PM, Zinner D, Rasoloarison R, Razafimantsoa L, Glos J, Andrianjanahary T (2005) Etudes sur la Biodiversité de Menabe Central. Unpublished Report. Durrell Wildlife Trust and Deutsches Primatenzentrum, Antananarivo, Madagascar

Duveiller G, Defourny P, Desclée B, Mayaux P (2008) Deforestation in Central Africa: estimates at regional, national and landscape levels by advanced processing of systematically-distributed Landsat extracts. Remote Sens Environ 112:1969-1981. doi: 10.1016/j.rse.2007.07.026

Etter A, McAlpine C, Wilson K, Phinn S, Possingham H (2006) Regional patterns of agricultural land use and deforestation in Colombia. Agric Ecosyst Environ 114:369-386. doi:10.1016/j. agee.2005.11.013

Fahrig L (2003) Effects of habitat fragmentation on biodiversity. Annu Rev Ecol Evol Syst 34:487-515. doi:10.1146/annurev. ecolsys.34.011802.132419 
Freudenberger K (2010) Paradise lost? Lessons from 25 Years of USAID Environment Programs in Madagascar. International Resources Group. United States Agency for International Development (USAID), Washington, USA http://www.usaid. gov/locations/sub-saharan_africa/countries/madagascar/ paradise_lost_25years_env_programs.pdf

Ganzhorn JU (1995a) Low-level forest disturbance effects on primary production, leaf chemistry, and lemur populations. Ecology 76:2084-2096. doi:10.2307/1941683

Ganzhorn JU (1995b) Cyclons over Madagascar: fate or fortune? Ambio 24:124-125. doi:10.2307/4314308

Ganzhorn JU, Schmid J (1998) Different population dynamics of Microcebus murinus in primary and secondary deciduous dry forests of Madagascar. Int J Primatol 19:785-796. doi:10.1023/ A:1020337211827

Ganzhorn JU, Sorg JP (Eds) (1996) Ecology and economy of a tropical dry forest in Madagascar. Primate Report 46:1-382

Ganzhorn JU, Rakotosamimanana B, Hannah L, Hough J, Iyer L, Olivieri S, Rajaobelina S, Rodstrom C, Tilkin G (1997) Priorities for biodiversity conservation in Madagascar. Primate Report 48:1-81

Ganzhorn JU, Fietz J, Rakotovao E, Schwab D, Zinner D (1999) Lemurs and the regeneration of dry deciduous forest in Madagascar. Conserv Biol 13:794-804. doi:10.1046/j. 1523-1739.1999.98245.x

Ganzhorn JU, Lowry PP, Schatz GE, Sommer S (2001) The biodiversity of Madagascar: one of the world's hottest hotspots on its way out. Oryx 35:346-348. doi:10.1046/j.1365-3008. 2001.00201.x

Gardner TA, Ribeiro-Júnior MA, Barlow J, Sauer Avila-Pires TC, Hoogmoed MS, Peres CA (2007) The value of primary, secondary, and plantation forests for a Neotropical herpetofauna. Conserv Biol 21:775-787. doi:10.1111/j.1523-1739. 2007.00659.x

Gardner TA, Barlow J, Sodhi NS, Peres CA (2010) A multi-region assessment of tropical forest biodiversity in a human-modified world. Biol Conservat 143:2293-2300. doi:10.1016/j.biocon. 2010.05.017

Geist HJ, Lambin EF (2002) Proximate causes and underlying driving forces of tropical deforestation. Bioscience 52:143-150. doi: 10.1641/0006-3568(2002)052[0143:PCAUDF]2.0.CO;2

Genini M (1996) Deforestation. Primate Report 46:49-55

Glaw F, Vences M, Böhme W (1998) Systematic revision of the genus Aglyptodactylus Boulenger, 1919 (Amphibia: Ranidae), and analysis of its phylogenetic relationships to other Madagascan ranid genera (Tomopterna, Boophis, Mantidactylus, and Mantella). J Zool Syst Evol Res 36:17-37. doi:10.1111/j. 1439-0469.1998.tb00775.x

Glos J, Dausmann KH, Linsenmair KE (2008) Modeling the habitat use of Aglyptodactylus laticeps, an endangered dry-forest frog from Western Madagascar. Monografie del Museo Regionale di Scienze Naturali di Torino 45:125-142

Goodman SM, Benstead JP (2005) Updated estimates of biotic diversity and endemism for Madagascar. Oryx 39:73-77. doi: $10.1017 /$ S0030605305000128

Goodman SM, Raselimanana A (2008) Exploration et connaissance biologique des différents sites inventoriés. Malagasy Nat $1: 33-45$

Gorenflo LJ, Corson C, Chomitz KM, Harper G, Honzák M, Özler B (2011) Exploring the association between people and deforestation in Madagascar. In: Cincotta RP, Gorenflo LJ (eds) Human population: its influences on biological diversity. Springer, Berlin, pp 197-221

Green GM, Sussman RW (1990) Deforestation history of the eastern rain forests of Madagascar from satellite images. Science 248:212-215. doi:10.1126/science.248.4952.212
Hannah L, Rakotosamimanana B, Ganzhorn JU, Mittermeier RA, Olivieri S, Iyer L, Rajaobelina S, Hough J, Andriamialisoa F, Bowles I, Tilkin G (1998) Participatory planning, scientific priorities, and landscape conservation in Madagascar. Environ Conserv 25:30-36. doi:10.1017/S0376892998000071

Hansen MC, Stehman SV, Potapov PV, Loveland TR, Townshend JRG, DeFries RS, Pittman KW, Arunarwati B, Stolle F, Steininger MK, Carroll M, DiMiceli C (2008) Humid tropical forest clearing from 2000 to 2005 quantified by using multitemporal and multiresolution remotely sensed data. P Natl Acad Sci USA 105:9439-9444. doi:10.1073/pnas.0804042105

Harper G, Steininger M, Tucker C, Juhn D, Hawkins F (2007) Fifty years of deforestation and forest fragmentation in Madagascar. Environ Conserv 34:1-9. doi:10.1017/S0376892907004262

Ingram JC, Dawson TP (2005) Inter-annual analysis of deforestation hotspots in Madagascar from high temporal resolution satellite observations. Int J Remote Sens 26:1447-1461. doi:10.1080/ 01431160412331291189

Innes JL (2010) Madagascar rosewood, illegal logging and the tropical timber trade. Madagascar Conserv Develop 5:6-10

Irwin MT, Wright PC, Birkinshaw C, Fisher B, Gardner CJ, Glos J, Goodman SM, Loiselle P, Rabeson P, Raharison JL, Raherilalao MJ, Rakotondravony D, Raselimanana A, Ratsimbazafy J, Sparks J, Wilmé L, Ganzhorn JU (2010) Patterns of species change in anthropogenically disturbed habitats of Madagascar. Biol Conserv 143:2351-2362. doi:10.1016/j.biocon.2010.01.023

IUCN (2011) IUCN Red List of threatened species. Version 2011.2. www.iucnredlist.org. (Downloaded on 11 April 2012)

Janzen DH (1988) Tropical dry forests: the most endangered major tropical ecosystem. In: Wilson EO (ed) Biodiversity. National Academy Press, Washington, pp 130-137

Laurance WF, Delamonica P, Laurance SG, Vasconcelos HL, Lovejoy TE (2000) Conservation: rainforest fragmentation kills big trees. Nature 404:836. doi:10.1038/35009032

Lerdau M, Whitbeck J, Holbrook NM (1991) Tropical deciduous forest: death of a biome. Trends Ecol Evol 6:201-233. doi: 10.1016/0169-5347(91)90019-T

Lowry PP II (1997) The classification of natural and anthropogenic vegetation in Madagascar. In: Patterson BD, Goodman SM (eds) Natural change and human impact in Madagascar. Smithsonian Institution, Washington, pp 93-123

Lugo AE, Helmer E (2004) Emerging forests on abandoned land: Puerto Rico's new forests. Forest Ecol Manag 190:145-161. doi: 10.1016/j.foreco.2003.09.012

Mertens B, Lambin EF (1997) Spatial modelling of deforestation in southern Cameroon: spatial disaggregation of diverse deforestation processes. Appl Geogr 17:143-162. doi:10.1016/S01436228(97)00032-5

Ministère de l'Environnement, des Eaux et Forêts (2006) Arrêté no 4532/2006-MINENVEF portant protection temporaire de l'Aire Protégée en création dénommée «Menabe central» Districts de Morondava, Belo sur Tsiribihina et Mahabo Région Menabe

Mittermeier RA, Langrand O, Lowry PP II, Schatz G, Gerlach J, Goodman SM, Steininger M, Hawkins F, Raminosoa N, Ramilijaona O, Andriamaro L, Randrianasolo H, Rabarison $\mathrm{H}$, Rakotobe ZL (2004) Madagascar and the Indian Ocean Islands. In: Lamoreux J, da Fonseca GAB, Mittermeier RA, Robles Gil P, Hoffman M, Pilgrim J, Brooks T, Goetsch Mittermeier C (eds) Hotspots revisited earth's biologically richest and most endangered ecoregions. CEMEX, Mexico City, pp 138-144

Moat J, Smith P (eds) (2007) Atlas of the Vegetation of Madagascar. Royal Botanic Gardens, Kew. http://www.vegmad.org/

Mon MS, Mizoue N, Htun NZ, Kajisa T, Yoshida S (2012) Factors affecting deforestation and forest degradation in selectively logged production forest: a case study in Myanmar. Forest Ecol Manag 267:190-198. doi:10.1016/j.foreco.2011.11.036 
Myers N, Mittermeier RA, Goetsch Mittermeier C, da Fonseca GAB, Kent J (2000) Biodiversity hotspots for conservation priorities. Nature 403:853-858. doi:10.1038/35002501

Nelson R, Horning N (1993) AVHRR-LAC estimates of forest area in Madagascar, 1990. Int J Remote Sens 14:1463-1475. doi: $10.1080 / 01431169308953981$

Rakotonirina (1996) Composition and structure of a dry forest on sandy soils near Morondava. Primate Report 46:81-87

Randriamalala H, Liu Z (2010) Rosewood of Madagascar: between democracy and conservation. Madagascar Conserv Develop $5: 11-22$

Rasoloarison RM, Goodman SM, Ganzhorn JU (2000) Taxonomic revision of mouse lemurs (Microcebus) in the western portions of Madagascar. Int J Primatol 21:963-1019. doi:10.1023/ A: 1005511129475

Razafimanantsoa L (2003) Mungotictis decemlineata, narrow-striped mongoose. In: Goodman SM, Benstead JP (eds) The natural history of Madagascar. The University of Chicago Press, Chicago, pp 1357-1360

Scales I (2011) Farming at the forest frontier: land use and landscape change in Western Madagascar, 1896-2005. Environ Hist 17:499-524. doi:10.3197/096734011X13150366551481

Scales I (2012) Lost in translation: conflicting views of deforestation, land use and identity in western Madagascar. Geogr J 178:67-79. doi:10.1111/j.1475-4959.2011.00432.x

Smith AP (1997) Deforestation, fragmentation, and reserve design in western Madagascar. In: Laurance WF, Bierregaard OW (eds) Tropical forest remnants: ecology, management and conservation of fragmented communities. The University of Chicago Press, Chicago, pp 415-441

Smith AP, Horning N, Moore D (1997) Regional biodiversity planning and lemur conservation with GIS in western Madagascar. Conserv Biol 11:498-512. doi:10.1046/j.1523-1739. 1997.95283.x

Sommer S, Toto Volahy A, Seal U (2002) A population and habitat viability assessment for the highly endangered giant jumping rat (Hypogeomys antimena), the largest extant endemic rodent of Madagascar. Anim Conserv 5:263-273. doi:10.1017/S136 7943002004018

Sorg JP (2006) Orientations nouvelles de la recherche dans la zone des forêts denses sèches à Madagascar. In: Schwitzer C, Brandt S, Ackermand D, Ramilijaona O, Randria G, Ganzhorn JU (eds) Proceedings of the German-Malagasy research cooperation in life and earth sciences. Concept Verlag, Berlin, pp 67-71
Sorg JP, Rohner U (1996) Climate and tree phenology of the dry deciduous forest of the Kirindy Forest. Primate Report 46:57-80

Sorg JP, Ganzhorn JU, Kappeler PM (2003) Forestry and research in the Kirindy Forest/Centre de Formation Professionnelle Forestière. In: Goodman SM, Benstead JP (eds) The natural history of Madagascar. The University of Chicago Press, Chicago, pp 1512-1519

Tidd ST, Pinder JE III, Ferguson GW (2001) Deforestation and habitat loss for the Malagasy flat-tailed tortoise from 1963 through 1993. Chelonian Conserv Biol 4:59-65

Vågen TG (2006) Remote sensing of complex land use change trajectories: a case study from the highlands of Madagascar. Agr Ecosyst Environ 115:219-228. doi:10.1016/j.agee.2006.01.007

Viña A, Echavarria FR, Rundquist DC (2004) Satellite change detection analysis of deforestation rates and patterns along the Colombia: Ecuador border. Ambio 33:118-125. doi:10.1579/ 0044-7447-33.3.118

Whitehurst AS, Sexton JO, Dollar L (2009) Land cover change in western Madagascar's dry deciduous forests: a comparison of forest changes in and around Kirindy Mite National Park. Oryx 43:275-283. doi:10.1017/S0030605309001756

Whitmore TC (2000) Madagascar deforestation rate during. In: Lourenço WR, Goodman SM (eds) Diversité et Endemisme à Madagascar. Mémoires de la Société de Biogéographie, Paris, p 125

Whitmore TC, Sayer JA (eds) (1992) Tropical deforestation and species extinction. Chapman \& Hall, New York

World Bank (2010) Governance and development effectiveness review. A political economy analysis of governance in Madagascar. World Bank, Report No. 54277-MG

WWF (2001) Madagascar Dry Deciduous Forests. http://www. worldwildlife.org/wildworld/profiles/terrestrial/at/ at0202_full.html. Accessed 03 December 2010

Yoder AD, Rasoloarison RM, Goodman SM, Irwin JA, Atsalis S, Ravosa MJ, Ganzhorn JU (2000) Remarkable species diversity in Malagasy mouse lemurs (Primates, Microcebus). Proc Natl Acad Sci USA 97:11325-11330. doi:10.1073/pnas.200121897

Young RP, Volahy AT, Bourou R, Lewis R, Durbin J, Wright TJ, Hounsome TD, Fa JE (2008) A baseline estimate of population size for monitoring the Endangered Madagascar giant jumping rat Hypogeomys antimena. Oryx 42:584-591. doi:10.1017/ S0030605307000816 